\title{
Erratum: The impact of COVID-19 on transport in South Africa
}

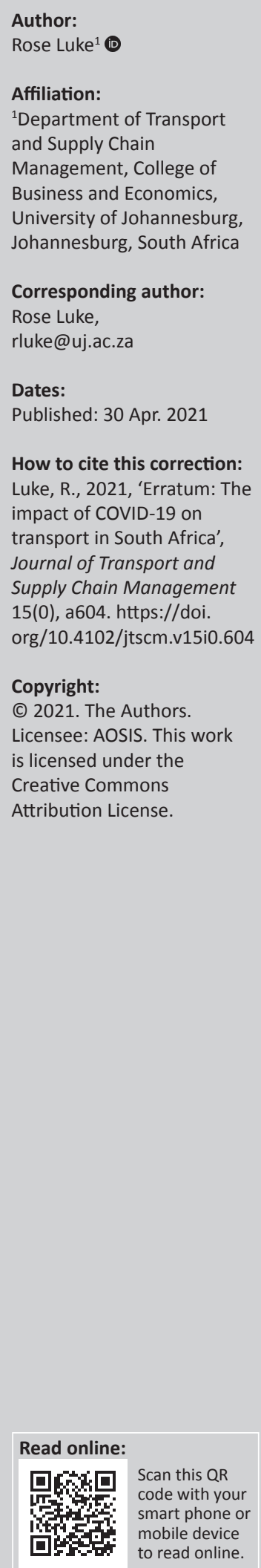

In the version of this article initially published, Luke, R., 2020, 'The impact of COVID-2019 on transport in South Africa', Journal of Transport and Supply Chain Management 14(0), a545. https:// doi.org/10.4102/jtscm.v14i0.545, the title of this manuscript has been incorrectly published as 'The impact of COVID-2019 on transport in South Africa'. The correct article title is 'The impact of COVID-19 on transport in South Africa'.

This correction does not alter the study's findings of significance or overall interpretation of the study's results. The publisher apologises for any inconvenience caused. 


\section{The impact of COVID-2019 on transport in South Africa}

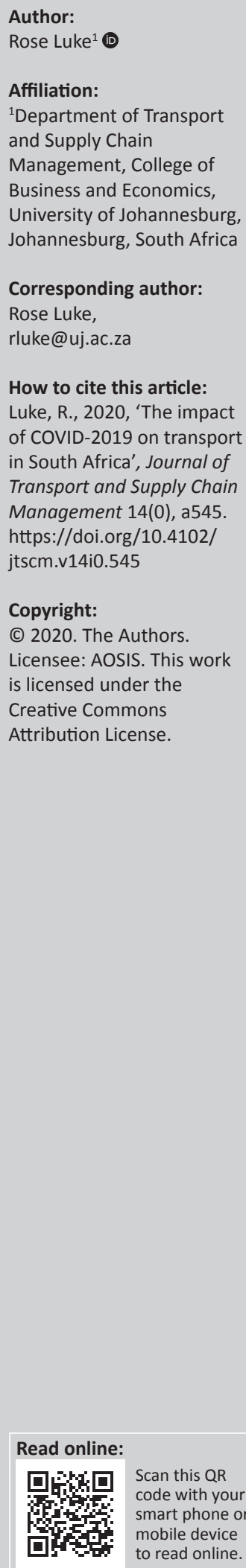

\section{Introduction}

In tough economic times, organisations face declining demand and, consequently, operational and financial constraints. Transport and logistics organisations are linked directly to the state of the economy, and the recessional traits impact the ability to operate effectively. At the beginning of 2020, South Africa had entered a recession, with the economy contracting by $1.4 \%$ in the last quarter of 2019, following a $0.8 \%$ contraction in the third quarter (Stats SA 2020b). Mining and manufacturing contributed to a further $2 \%$ contraction in the first quarter of 2020 (Stats SA 2020b), bringing in the third consecutive contraction. In the midst of this, on $11 \mathrm{March}$ 2020, the World Health Organization declared the coronavirus disease 2019 (COVID-19) a pandemic, and on 27 March 2020, South Africa declared some of the world's toughest lockdown restrictions (BBC 2020) in an effort to contain the virus. With the banning of alcohol and tobacco sales, the closure of international borders and the directive for people to stay at home, the effect on the economy was almost instantaneous. 'Gross domestic product (GDP) fell by just over $16 \%$ between the first and second quarters of 2020, giving an annualised growth rate of $-51 \%$ ' (Stats SA 2020d). The manufacturing industry, the trade, catering and accommodation industry, the transport, storage and communication industry, and the mining and quarrying industry each decreased by between 65\% and 75\% (Moneyweb 2020), and household expenditure 'slumped by $49.8 \%$ in line with the closure of hotels, restaurants, transport services, recreational facilities and many stores. Spending on restaurants and hotels ground to an almost complete halt, plunging by 99.9\%' (Stats SA 2020d). With this massive contraction, the question is raised as to the impact this has had and will have on transport, logistics and supply chains in the country.

\section{Public transport}

Public transport has been at the forefront of the transport discussion during COVID-19, with taxis dominating the news in recent months. With distance, dose and dispersion being the key factors in the spread of the virus (Allais et al. 2020), maintaining social distance and reducing the time spent in confined spaces is almost impossible for taxi commuters. Despite government's efforts to enforce lower occupancy levels (Simelane 2020b,' Taxis at 70 percent capacity are now allowed - if all passengers wear surgical masks'), the taxi industry defied this by loading vehicles at $100 \%$ capacity (Simelane 2020a, 'Passengers at risk of COVID-19 as taxi operators violate lockdown regulations'). This has highlighted several aspects that are fundamental to the industry, namely, the thin profit margins (Fobosi 2020), the informal and often lawless nature (Peter 2019; Power Digital 2020), the (frequently) captive nature of the user (Simelane \& Pikoli 2020, 'Rail, bus and taxi organisations scramble as they mobilise to fight COVID-19') and the political power of the business, as evidenced by government's concession to allow loading to $100 \%$ of passenger capacity whilst still enforcing $70 \%$ in trains (Business Insider SA 2020). Together with government's offer of a bailout to the industry (Fobosi 2020), these features highlight the importance of the industry to commuters and the economy. It thus becomes critical that the industry be recognised as a key element of the public transport landscape in the country, which therefore requires recognition, regulation, formalisation and subsidisation, at a level that would benefit commuters and ensure the sustainability of the industry.

Other forms of public transport, such as buses and trains, have borne the brunt of the lockdown regulations. Although subsidised, subsidies have not kept pace with increases in costs in recent years (Bothma 2020), and most public transport operators are at least partially dependent on ticket sales. The implication is that the reduction in passenger numbers resulting from movement restrictions, compounded by directives regarding capacity loading (Seleka 2020), has reduced a large portion of these operators' income. This leads to concerns regarding the sustainability of 
many of the operators, where subsidy levels are usually too low (Bothma 2020) and viability is also dependent on the revenue generated from commuters (Mahlangu 2020); the immediate threat is a reduction of services (Bothma 2020) and therefore the mobility of the people most in need of subsidised transport services.

\section{Disruptive transport services}

Services such as Uber have had mixed experiences. Whilst there has been a certain level of success in the rise of Uber Eats (Bellon \& Rana 2020), generally, the restriction of people movement across the globe (Connor 2020), the closure of bars and restaurants (Bauer 2020) and the general fear of being in an enclosed car with a stranger who has been in contact with numerous other strangers (Statista 2020) has led to a major weakening in ride-share company fortunes, with Uber reporting as much as a $70 \%$ decline in patronage worldwide (Bellon \& Rana 2020). Whilst it is assumed that the company has suffered similar losses in South Africa, and anecdotal evidence suggests that some Uber drivers have had to return their vehicles to financiers, companies such as Lyft, Bolt and Uber are showing signs of recovery with reduced travel restrictions (Lee 2020; Reuters Staff 2020). In South Africa, Uber has extended its service offering into parcels (Fin24 2017) and business deliveries (Business Tech 2020a), which has helped to absorb some of the revenue losses from the reduction of the passenger base; however, the pandemic has highlighted the vulnerability of gig drivers to shock (Anwar 2020).

\section{Traffic and car sales}

A major impact of the initial lockdown was the much-touted improvement in air quality (Lister \& Thornton 2020), the result of the restriction of both people and goods movement. As an inevitable consequence of regulation both locally and internationally, it provided food for thought as to the air quality, and, given the new fresh feel in cities, gave rise to much speculation on what the future of movement in cities should be (Rapid Transition Alliance 2020). However, we quickly forget. With many people not yet ready to brave the proximity of public transport, cars remain at the forefront of people movement and continue to dominate the urban commuter market (Anderson 2020). People movement started to increase with the lifting of restrictions to level 2 (Boje 2020), as did road freight (southcapenet 2020).

Another area of significant impact has been vehicle sales. This tends to be largely impacted by the state of the economy (European Automobile Manufacturers Association 2018), and with the contraction in three previous quarters prior to lockdown, vehicle sales had already started falling (Hancock 2019; Kruger 2020). The level of vehicle sales has contracted significantly since then, with domestic sales $26.3 \%$ lower in August 2020, compared to August 2019, and export sales reflecting a decline of $46.9 \%$ in the same period (Motoring South Africa 2020). In South Africa, where the used car sales market normally tends to be buoyant, even this sector initially contracted, with the market price reduced by an inflow of vehicles from rental fleets, de-fleeting because of a lack of business (Business Tech 2020b). However, this sector has lately shown some resilience, with online searches showing considerable increases since August (Gilham 2020). This reflects the inherent resilience of this section of the car sales market and perhaps a concern to the commuting future, where more cars are envisioned.

\section{Freight transport}

From a logistics perspective, as the regulations associated with COVID-19 have resulted in major economic contraction in the country, it is inevitable that the logistics companies have also seen major upheavals. With the initial ban on the sales of many items, the reduction in goods movements and the consequent contraction of the retail sector (Stats SA 2020d), the impact on trucking and logistics companies was immediate (Stats SA 2020d). From a reduction in vehicle movements (Waterworth 2020) to driver retrenchments (Mzobe 2020), it is estimated that the impact has led to an overall industry contraction of $67.9 \%$ in the last quarter (Stats SA 2020c). However, uncertainty in government regulation has had the greatest impact by far. The banning, unbanning, re-banning and re-unbanning of alcohol sales, for example, has meant the impossibility of accurate forecasting and therefore planning. The impact has been severe, with many small companies expected to not survive (22onSloane 2020) and larger companies struggling to cope with non-operational areas of business in levels 4 and 5 lockdown, warehousing demand spikes, potential inflationary impacts and uncertain regulatory pressures (IOL 2020).

Freight rail and shipping are similarly impacted by the regulations on goods movement and the lower quantities moved. The initial closure of international borders for all but the most essential goods implied an instant contraction of the economy and of goods movement. In level 5, trade to and from South Africa dropped by 3\% initially (Viljoen 2020), and many goods were left stranded in ports, yards and warehouses across the country as a result of the movement regulations (Bezuidenhout 2020). With the further reduction in imports and exports, port operations initially scaled back to operating at $60 \%$ capacity (bizcommunity 2020), and Transnet Freight Rail announced an immediate scale-down of operations following the declaration of the initial lockdown (International Railway Journal 2020). Although there are signs of improvement, particularly following the easing of restrictions to level 2, Transnet (both ports and freight rail) still shows depressed activity (Magubane 2020).

However, not all logistics companies have suffered from this. Small start-ups (Fin24 2017) plan to serve the growing home delivery market (Madubela 2020). Large online retailers such as Takealot have increased sales significantly (McKane 2020), and previously store-based retailers have scrambled to place their products online (Thompson 2020). This has led to a growing demand for last-mile delivery capacity (Broll 2020) and the burgeoning of the courier industry (SA Trucker 
2020). The demand for capacity has also seen a shift in the market, particularly with the increase in informal delivery services. In many cases, Uber and Bolt drivers have shifted focus from the passenger to the freight market, reflecting the ability of the less formal gig sector worker to adapt to changing market needs and the resilience of the smaller operator.

\section{Air transport}

The contraction of the air transport sector globally (ICAO 2020 ) is the result of restrictions on people movement and the closure of many international borders (IATA 2020). A change in consumer spending patterns and reduced demand for most goods, barring the essentials (Accenture 2020), has implied lower levels of movements for the luxury items generally moved by air (D'Arpizio et al. 2020). On the contrary, the increasing demand for medicines (IANS 2020) and computer and related equipment (Kan 2020) has implied that the air freight market has not declined completely, although supply chains have struggled to keep up (Kan 2020). In South Africa, the upheavals in the air transport industry were more severe than elsewhere. With South African Airways (SAAs) tumultuous past, resulting in continuous losses and bailouts, business rescue became a reality in December 2019 (Smith 2019, 'SAA business rescue: Creditors have first meeting'). Soon kulula followed suit, going into business rescue in May 2020 (Comair Limited 2020), leaving a major lacuna in the industry. Whilst the contraction of the sector resulting from COVID-19 regulations has meant that this has not led to capacity constraints in the short term, the real question is, what now? With government proposing a new airline (Skiti 2020), kulula anticipating a return to the air in November 2020 and former kulula chief executive officer Gidon Novick announcing a possible venture with Global Aviation to create a new airline (African Aerospace 2020), on the surface, the future of the airline industry appears promising. Current survivors in the domestic market include companies such as FlySafair and Airlink (IATA 2020; Smith 2020; 'Coronavirus impact on African aviation worse than initially estimated') in the short term, although the contraction of the economy may have changed the demand for domestic services for years to come. With the proposed new and renewed capacity entering the market, the question is really whether the market will continue to exist in its current form, especially given the contraction in demand. Ongoing restrictions on international travel and tourism and changes in the ways of doing business (Bell 2020) also imply, however, that the future of international air travel may have changed forever (Bilotkach 2020).

\section{Conclusion}

As the sector that binds the economy, transport is not only essential to the functioning of the economy, but it also bears the brunt of any changes in economic activity. Whilst some agriculture and food retailers have survived the churn, most of the economy has contracted, implying that most of the transport sector has also contracted. Logistics companies have generally been hard hit (Egloff 2020), and their survival/ recovery is almost entirely dependent on the ability to adapt to the new world (Egloff 2020) and sound economic policy to aid the failing economy (National 2020). Coronavirus disease 2019 has certainly brought to the fore the government's reliance on the minibus taxi industry to pick up the slack in the provision of public transport (Fobosi 2020). Government has stated that this highlights the necessity of assisting the industry through subsidies, which can only be achieved through more formalisation (eNCA 2020; Meyer 2020). Given the lack of success of formalisation in the past, as well as the industry's informal nature and fierce independence, it is not yet clear whether this is affordable, achievable or even desirable, taking into account the track record with undersubsidisation of public transport services (Bothma 2020; Gedye 2020). The discussions about subsidisation and regulation of the minibus taxi industry also leave untouched the question of the rest of the public transport sector. What of the many commuters who are captive to the lower-priced, subsidised rail and bus services? The Passenger Rail Agency of South Africa (PRASA) has started to see some increase in operations (Mercury Reporter 2020), but it needs a dramatic turnaround to enable it to fulfil its role as the rail commuter service provider to the country (Ntsidi 2020). And what of the underfunded commuter bus industry? And the commuters? Transport infrastructure investment is also likely to be badly impacted in the near future, with South African National Roads Agency Ltd (SANRAL) and the Gautrain Management Agency being two of five transport institutions that cut spending in 2018/2019 (Stats SA 2020e), the contraction of the economy is likely to further curtail much-needed transport infrastructure spending. It is thus evident that clear and consistent economic policy is required for recovery, and transport policy needs to follow suit. People and goods need to be able to move easily, affordably and safely. Existing policies such as the White Paper on National Transport Policy (Department of Transport 1996), and the newish Draft White Paper on National Transport Policy (Department of Transport 2017), recognise the importance of subsidisation, tendering, infrastructure improvements and other measures to transform transport into a sector that can provide a solid support structure to the entire economy, but the policies have not yet brought about the changes required to enable the effective and efficient movement of people and goods. Coronavirus disease 2019 restrictions have highlighted the essential nature of the industry and the centrality of transport in a postCOVID-19 world (Budd \& Ison 2020). Without clear economic policy, the economy will have little chance of recovery; without a sound supporting transport sector, recovery will be impossible. If ever there was a time for understanding that transport is crucial to the socio-economic success of the country, a time for robust debate, meaningful public and industry participation, as well as clear strategic direction that fosters development and transformation, hard decisions and strong political will, post-COVID-19 would be that time. 


\section{References}

22onSloane, 2020, Covid-19: Impact on South Africa's SMMEs, viewed 12 Septembe 2020, from http://ugu.gov.za/Documents/COVID-19\%20SMME/COVID-19\%20 Impact $\% 20$ on\%20South\%20Africa\%20SMMEs.pdf

Accenture, 2020, COVID-19: How consumer behavior will be changed, viewed 02 September 2020, from https://www.accenture.com/us-en/insights/consumergoods-services/coronavirus-consumer-behavior-research.

African Aerospace, 2020, Novick's plan for new South African carrier boosted by global deal, viewed 15 September 2020, from https://www.africanaerospace.aero/ novick-s-plan-for-new-south-african-carrier-boosted-by-global-deal.html.

Allais, L. et al., 2020, Distance, dose, dispersion: An experts' guide on Covid-19 risks in South Africa and how to manage them, viewed 09 September 2020, from https:// www.dailymaverick.co.za/article/2020-06-26-distance-dose-dispersion-anexperts-guide-on-covid-19-risks-in-south-africa-and-how-to-manage-them/.

Anderson, B., 2020, Coronavirus pandemic will prompt more to commute in cars rather than use public transport, viewed 12 September 2020, from https://www. carscoops.com/2020/08/coronavirus-pandemic-will-prompt-more-to-commutein-cars-rather-than-use-public-transport/.

Anwar, M.A., 2020, "We work for Uber": South Africa's gig drivers left alone at the wheel, viewed 09 September 2020, from https://africanarguments.org/2020/04/28/ we-work-for-uber-south-africa-covid-19-gig-drivers-alone-wheel/

Bauer, N., 2020, Level 5 to 4: South Africa plans to reopen economy, in phases, viewed 11 September 2020, from https://www.aljazeera.com/ajimpact/level-5-4-southafrica-plans-reopen-economy-phases-200424160114471.html.

BBC, 2020, Coronavirus: South Africa eases lockdown as 'outbreak reaches peak, viewed 08 September 2020, from https://www.bbc.com/news/world-africa-53795339.

Bell, I., 2020, Coronavirus could change the way we do business for the better, viewed 29 August 2020, from https://www.businesswest.co.uk/blog/coronavirus-couldchange-way-we-do-business-better.

Bellon, T. \& Rana, A., 2020, Uber rides take Covid-19 hit but food-delivery business doubles, viewed 07 September 2020, from https://www.iol.co.za/businessreport/international/uber-rides-take-covid-19-hit-but-food-delivery-business doubles-805e96ee-fb83-46c1-bcec-ddb61948de25.

Bezuidenhout, J., 2020, Covid-19 lockdown: A moving target for importers, viewed 29 August 2020, from https://www.dailymaverick.co.za/article/2020-03-25-covid19-lockdown-a-moving-target-for-importers/.

Bilotkach, V., 2020, Coronavirus will affect the airline industry for years to come -but not all of it will be bad, viewed 13 September 2020, from https://www. not all of it will be bad, viewed 13 September 2020, from https://www. independent.co.uk/travel/news-ants-covid-19-a9418971.html.

bizcommunity, 2020, The Covid-19 impact on global shipping and SA's economy, viewed 12 September 2020, from https://www.bizcommunity.com/ viewed 12 September

Boje, V., 2020, Level 2 sees people get out and about after nearly five months, viewed 02 September 2020, from https://www.iol.co.za/pretoria-news/news/level-2 sees-people-get-out-and-about-after-nearly-five-months-7e99bb99-6c3b-4f3cb7aa-17d54da0e083.

Bothma, S., 2020, Putco commuters left in the lurch, viewed 12 September 2020, from https://rekordeast.co.za/281702/putco-commuters-left-in-the-lurch/.

Broll, 2020, Broll report looks at SA's shifting last-mile delivery landscape, viewed 05 September 2020, from https://www.bizcommunity.com/Article/196/168/207852. html.

Budd, L. \& Ison, S., 2020, 'Responsible transport: A post-COVID agenda for transport policy and practice', Transport Research Interdisciplinary Perspectives 6, 100151. policy and practice', Transport Research Interd
https://doi.org/10.1016/j.trip.2020.100151

Business Insider SA, 2020, It's official: Minibus taxis may be 100\% full from today, but trains only $70 \%$, viewed 03 September 2020, from https://www.businessinsider. co.za/minibus-taxis-may-now-be-100-full-2020-7.

Business Tech, 2020a, South Africa's used cars are suddenly much cheaper - Here's why, and what they cost, viewed 13 September 2020, from https://businesstech. co.za/news/motoring/408291/south-africas-used-cars-are-suddenly-muchcheaper-heres-why-and-what-they-cost/.

Business Tech, 2020b, Uber launches delivery app for businesses in South Africa, viewed 12 September 2020, from https://businesstech.co.za/news/it-services/388369/ uber-launches-delivery-app-for-businesses-in-south-africa/.

Comair Limited, 2020, Comair enters business rescue in response to unprecedented circumstances resulting from Covid-19, viewed 01 September 2020, from https:// www.comair.co.za/media-room/Comair-enters-business-rescue-in-response-tounprecedented-circumstances.

Connor, P., 2020, More than nine-in-ten people worldwide live in countries with travel restrictions amid COVID-19, viewed 16 September 2020, from https://www. restrictions amid COVID-19, viewed 16 September 2020, from https://wWW.
pewresearch.org/fact-tank/2020/04/01/more-than-nine-in-ten-peoplepewresearch.org/fact-tank/2020/0
worldwide-live-in-countries-with-travel-restrictions-amid-covid-19/.

D’Arpizio, C., Levato, F., Fenili, S., Colacchio, F. \& Prete, F., 2020, Luxury after Covid-19: Changed for (the) Good?, viewed 03 September 2020, from https://www.bain. com/insights/luxury-after-coronavirus/.

Department of Transport, 1996, White Paper on national transport policy, Republic of South Africa, Pretoria.

Department of Transport, 2017, Draft revised white paper on national transport policy 2017, Republic of South Africa, Pretoria.

Egloff, C., 2020, Hit hard by COVID-19, transportation \& logistics companies must adapt to keep supplies moving, viewed 12 September 2020, from https://www. bcg.com/en-za/hit-hard-by-covid-19-transportation-logistics-companies-mustadapt-to-keep-supplies-moving.
eNCA, 2020, Mbalula wants regulated, formalised taxi industry, viewed 30 August 2020, from https://www.enca.com/news/taxi-industry-will-be-fully-regulatedmbalula.

European Automobile Manufacturers Association, 2018, Vehicle sales mirror economic growth (2006-2019 trend), viewed 03 September 2020, from https://www.acea. be/statistics/article/vehicle-sales-mirror-economic-growth-2006-2019-trend.

Fin24, 2017, SA start up's Uber solution for parcel delivery, viewed 01 September 2020, from https://www.news24.com/fin24/tech/news/sa-start-ups-uber-solution-forparcel-delivery-20170116.

Fobosi, S., 2020, South Africa's minibus taxi industry has been marginalised for too long. This must change, viewed 03 September 2020, from https://theconversation. $\mathrm{com} /$ south-africas-minibus-taxi-industry-has-been-marginalised-for-too-longthis-must-change-142060.

Gedye, L., 2020, Public transport inequality, viewed 03 September 2020, from https:// mg.co.za/article/2020-02-25-public-transport-inequality/.

Gilham, S., 2020, Used is the brand new 'new': Interest in SA second-hand car market surges, viewed 13 September 2020, from https://www.thesouthafrican.com/ motoring/sa-autotrader-used-car-sales-report-2020\%.

Hancock, T., 2019, New-vehicle sales decline indicative of economic health, viewed 12 September 2020, from https://www.engineeringnews.co.za/article/new-vehiclesales-decline-indicative-of-economic-health-2019-07-26\#: : text=There $\% 20$ is $\% 20$ a $\% 20$ close $\% 20$ correlation, rate $\% 2 \mathrm{C} \% 20$ he $\% 20$ tells $\% 20$ Engineering $\% 2$ News.\&text $=$ In $\% 20$ the $\% 20$ first $\% 2$ half $\% 20$ of $\% 20$ the $\% 20$ year $\% 2 \mathrm{C} \% 2$ vehicl.

IANS, 2020, Covid-19 changes medication needs of masses, viewed 19 August 2020, from https://health.economictimes.indiatimes.com/news/pharma/covid-19-changesmedication-needs-of-masses/75221850.

IATA, 2020, Recovery delayed as international travel remains locked down, viewed 30 August 2020, from https://www.iata.org/en/pressroom/pr/2020-07-28-02/.

ICAO, 2020, Economic impacts of COVID-19 on civil aviation, viewed 12 September 2020, from https://www.icao.int/sustainability/Pages/Economic-Impacts-ofCOVID-19.aspx.

International Railway Journal, 2020, Transnet scales back rail operation as South Africa enters lockdown, viewed 12 September 2020 from https://www railjournal. com/freight/transnet-scales-back-rail-operation-as-south-africa-enterslockdown/.

IOL, 2020, Covid-19: Impact of lockdown on transport, distribution and warehousing, viewed 12 September 2020, from https://www.iol.co za/business-report/covid viewed 12 September 2020, from https://www.iol.co.za/business-report/covid-
19 -impact-of-lockdown-on-transport-distribution-and-warehousing-47339810.

Kan, M., 2020, https://health.economictimes.indiatimes.com/news/pharma/covid19-changes-medication-needs-of-masses/75221850, viewed 01 September 2020 from https://www.pcmag.com/news/covid-19-creates-soaring-demand-for-pcsbut-the-surge-isnt-expected-to.

Kruger, A., 2020, Car sales expected to remain subdued, viewed 12 September 2020, from https://www.moneyweb.co.za/news/economy/car-sales-expected-toremain-subdued/\#: : :text=Figures $\% 20$ from $\% 20$ the $\% 20$ National $\% 20$ Association, declining $\% 20$ by $\% 20$ at $\% 2$ least $\% 204 \% 25$.

Lee, D., 2020, Lyft clings to signs of recovery after pandemic dents revenue, viewed 14 September 2020, from https://www.ft.com/content/938ea146-2699-4c2d-8511e634d2d003f8.

Lister, A. \& Thornton, L., 2020, Improvements in Air Quality during the pandemic - Can they be sustained? viewed 18 August 2020, from https://airqualitynews. com/2020/06/18/improvements-in-air-quality-during-the-pandemic-can-theybe-sustained/.

Madubela, A., 2020, SA's booming online sales: Will they refashion our world?, viewed 01 September 2020, from https://www.news24.com/fin24/companies/retail/sasbooming-online-sales-will-they-refashion-our-world-20200824.

Magubane, K., 2020, Gordhan: Covid-19 the ultimate test of Transnet's renewal viewed 04 September 2020, from https://www.news24.com/fin24/companies/ industrial/gordhan-covid-19-the-ultimate-test-of-transnets-renewal-20200902.

Mahlangu, I., 2020, Passenger bus sector does U-turn on pay hikes, viewed 01 September 2020, from https://www.sowetanlive.co.za/news/south-africa/2020 07-10-passenger-bus-sector-does-u-turn-on-pay-hikes/.

McKane, J., 2020, Big growth for Takealot and Mr D Food, viewed 07 September 2020, from https://mybroadband.co.za/news/business/358001-big-growth-for-takealotand-mr-d-food-2.html\#: : text=\%E2\%80\%9CTakealot $\% 2$ C $\% 20$ South $\% 20$ Africa's $\% 2$ number $\% 201$,local $\% 20$ currency $\% 2$ C $\%$ E2 $\% 80 \% 9 \mathrm{D} \% 20$ Naspers $\% 20$ said.\&text=Takealot $\% 20$ recorded $\% 20$ revenue $\% 20$ growth $\% 20$ of, $\% 25 \% 20$.

Mercury Reporter, 2020, PICS: Prasa set to resume partial train services between uMlazi and KwaMashu, viewed 01 September 2020, from https://www.iol.co.za/ mercury/news/pics-prasa-set-to-resume-partial-train-services-between-umlaziand-kwamashu-50220507.

Meyer, D., 2020, Taxi Lekgotla: Mbalula wants to 'dignify industry' through formalisation, viewed 14 September 2020, from https://www.thesouthafrican. $\mathrm{com} /$ news/taxi-lekgotla-mbalula-santaco-gauteng-thursday-20-august-2020/.

Moneyweb, 2020, GDP collapses $51 \%$ in the second quarter, viewed 08 September 2020, from https://www.moneyweb.co.za/news/south-africa/gdp-collapses-forthe-second-quarter/.

Motoring South Africa, 2020, Naamsa: 26.3\% year-on-year August decline despite Level 2 vehicle sales, viewed 15 September 2020, from https://www. thesouthafrican.com/motoring/naamsa-august-2020-new-vehicle-sales/.

Mzobe, S., 2020, List of trucking companies that have either retrenched employees or closed down due to Covid-19, viewed 12 September 2020, from https://satrucker. co.za/list-of-trucking-companies-that-have-either-retrenched-employees-orclosed-down-due-to-covid-19/. 
National, T., 2020, Sound economic policy is crucial for a speedy economic recovery, IMF says, viewed 13 September 2020, from https://www.thenational.ae/ business/sound-economic-policy-is-crucial-for-a-speedy-economic-recovery-imfsays-1.1000422.

Ntsidi, E., 2020, Vandalism, Covid-19 derailing struggling PRASA's efforts to get back on its feet, viewed 22 August 2020, from https:/lewn.co.za/2020/09/11/ vandalism-covid-19-derailing-struggling-prasa-s-efforts-to-get-back-on-its-feet.

Peter, Z., 2019, Violence, lawlessness a normal part of the journey, say taxi commuters, viewed 02 September 2020, from https://www.news24.com/citypress/news/ violence-lawlessness-a-normal-part-of-the-journey-say-taxi-commuters20190228.

Power Digital, 2020, Transport department denounces taxi operators' lawlessness, viewed 01 September 2020, from https://www.power987.co.za/news/transportdepartment-denounces-taxi-operators-lawlessness/.

Rapid Transition Alliance, 2020, Unnecessary travel? The return of breathable air and rethinking transport in a crisis, viewed 29 August 2020, from https://www. resilience.org/stories/2020-04-29/unnecessary-travel-the-return-of-breathableair-and-rethinking-transport-in-a-crisis/.

Reuters Staff, 2020, Uber signals recovery in rides as lockdown restrictions ease, viewed 08 September 2020, from https://www.reuters.com/article/us-healthcoronavirus-uber/uber-signals-recovery-in-rides-as-lockdown-restrictions-easeidUSKBN23A385.

SA Trucker, 2020, 9 Trucking businesses that you can choose to venture into in South Africa, viewed 12 September 2020, from https://satrucker.co.za/9-truckingbusinesses-that-you-can-choose-to-venture-into-in-south-africa/.

Seleka, N., 2020, Lockdown level 3: Curfews to be lifted for public transport, viewed 12 September 2020, from https://www.news24.com/news24/southafrica/news/ lockdown-level-3-curfews-to-be-lifted-for-public-transport-20200530.

Simelane, B., 2020a, Passengers at risk of Covid-19 as taxi operators violate lockdown regulations, viewed 01 September 2020, from https://www.dailymaverick.co.za/ article/2020-06-30-passengers-at-risk-of-covid-19-as-taxi-operators-violatelockdown-regulations/.

Simelane, B., 2020b, Taxis at 70 percent capacity are now allowed - If all passengers wear surgical masks, viewed 01 September 2020, from https://www. dailymaverick.co.za/article/2020-04-02-taxis-at-70-percent-capacity-are-nowallowed-if-all-passengers-wear-surgical-masks/.

Simelane, B. \& Pikoli, Z., 2020, Rail, bus and taxi organisations scramble as they mobilise to fight Covid-19, viewed 01 September 2020, from https://www. dailymaverick.co.za/article/2020-03-18-rail-bus-and-taxi-organisations-scrambleas-they-mobilise-to-fight-covid-19/.
Skiti, S., 2020, viewed 03 September 2020, from https://mg.co.za/business/2020-06 16-saa-2-0-hopes-to-start-lean-and-grow-from-next-year/.

Smith, C., 2019, SAA business rescue: Creditors have first meeting, viewed 14 September 2020, from https://www.news24.com/fin24/Companies/Industrial/ saa-business-rescue-creditors-have-first-meeting-20191220.

Smith, C., 2020, Coronavirus impact on African aviation worse than initially estimated says IATA, viewed 01 September 2020, from https://www.news24.com/fin24/ companies/industrial/coronavirus-impact-on-african-aviation-worse-thaninitially-estimated-says-iata-20200818.

southcapenet, 2020, Freight \& transport index shows some sectors reflect massive drop in activity, viewed 12 September 2020, from https://www.thegremlin.co. $\mathrm{za} / 2020 / 08 / 28 /$ freight-transport-index-shows-some-sectors-reflect-massivedrop-in-activity/.

Statista, 2020, Ride-hailing service usage in U.S. communities with COVID-19 spread 2020, viewed 06 September 2020, from https://www.statista.com/ statistics/1105008/covid-19-impact-ride-hailing-service-usage-us/.

Stats SA, 2020a, Economy slips into recession, viewed 08 September 2020, from http://www.statssa.gov.za/?p=13049.

Stats SA, 2020b, GDP falls by $2.0 \%$, viewed 08 September 2020, from http://www. statssa.gov.za/?p=13401.

Stats SA, 2020c, Gross domestic product. Second quarter 2020, viewed 12 September 2020, from http://www.statssa.gov.za/publications/P0441/P04412ndQuarter 2020.pdf

Stats SA, 2020d, Steep slump in GDP as COVID-19 takes its toll on the economy, viewed 08 September 2020, from http://www.statssa.gov.za/?p=13601.

Stats SA, 2020e, EBA spending on transport declines, viewed 12 September 2020, from http://www.statssa.gov.za/?p=13570.

Thompson, A., 2020, South African small businesses are going online due to the COVID-19 pandemic, viewed 15 September 2020, from https://www. investcapetown.com/south-african-small-businesses-are-going-online-due-tothe-covid-19-pandemic/.

Viljoen, W., 2020, South Africa's trade for March 2020 - Significant trade surplus shows the initial impact of COVID-19 on imports, viewed 09 September 2020, from https:// www.tralac.org/blog/article/14591-south-africa-s-trade-for-march-2020-significantwww.tralac.org/blog/article/14591-south-africa-s-trade-for-march-2020-significanthtml\#: : text=The $\% 20 \mathrm{impact} \% 20$ of $\% 20$ the $\% 20$ Covid,and $\% 20$ ht $m I \#: \sim$ : text $=$ The $\% 20$ impact $\%$
trade $\% 2$ Dcentred $\% 20$ less $\% 20$ around.

Waterworth, T., 2020, Vehicle tracking companies show movement has dropped $75 \%$ during lockdown, viewed 10 September 2020, from https://www.iol.co.za/ios/ during lockdown, viewed 10 September 2020, from https://www.iol.co.za/ios/
news/vehicle-tacking-companies-show-movement-has-dropped-75-duringlockdown-46583428. 